takes a somewhat outdated view. The friendship between philosopher and politician began in 1666 and continued until Shaftesbury's death in 1683, during which time Locke lived for some 14 years in the Earl's household. The two great men formed a unique and fruitful partnership of a theoretical with a practical mind. Whatever Professor Jeffreys may say of Shaftesbury, Locke was his lifelong friend and said of him that he was a "vigorous and indefatigable champion of civil ecclesiastical liberty." These are almost precisely the same words with which the professor acclaims Locke, and his article ends with praise of Locke's truthfulness.

In 1674 Locke received a bachelorship of medicine and was appointed to a medical studentship at Christ Church. In the following year he went to France for the sake of his health, and complained to a friend, "I doubt whether all the ortolans in France be able to communicate to me one grain of their fat." In 1679 Locke returned to England where he continued his association with Shaftesbury. He did not follow him into exile and was living in Clapham when Shaftesbury died in Holland. He then stayed in England long enough to go down to Dorset to assist at the return of his patron's body and to receive from the widow three yards of black cloth for his mourning suit He then withdrew to Holland, deeming the intolerant climate of England too dangerous for him. With a characteristic Stuart gesture Charles II ordered his dismissal from the studentship at Christ Church. After the revolution Locke returned and spent his last few years in the household of Lady Masham.

Your colleagues, Sir, may care to be reminded that an excellent if brief biography of Locke is to be found in An Alabama Student and other Biographical Essays by William Osler, Regius Professor of Medicine at Oxford, published in 1909.-I am, etc.,

Durley, Southampton

HIIDA M. STOWELL

\section{Non-union of the Scaphoid}

SIR,-Of course you are right when you state in your leading article (5 October, p. 2) that the problems of non-union of fractures of the scaphoid are best avoided by proper management of the original injury. However, I cannot agree with your implication that this ideal may be achieved simply by early recognition and plaster immobilization of the fracture; a significant number of these fractures fail to unite even when a scaphoid plaster is applied immediately after the injury and worn continuously for several months. Proper management of the injury demands an awareness of the different types of fracture and of their differing behaviour; I believe that unstable fractures have a high incidence of non-union and that this complication is best avoided by early internal fixation using a compression screw. ${ }^{1}$

With established non-union of the scaphoid the problem is different since there is frequently evidence of carpal instability. ${ }^{2}$ It is this instability which is commonly responsible for the weakness of the wrist, the susceptibility of further injury, and the radiocarpal osteoarthritis. Treatment of the ununited fracture obviously depends on the degree of instability. Screw fixation, simply by stabilizing the fracture and hence the midcarpal joint, may produce considerable relief of symptoms even if union does not always follow. Anterior grafting, either by the Russe technique or by the use of a bone wedge, may help to restore the normal anatomy but has the disadvantage of requiring a fairly long period in plaster. If there is evidence of radiocarpal osteoarthritis then radial styloidectomy either alone or combined with other procedures usually affords considerable symptomatic relief. Obviously in the most severe cases wrist arthrodesis may be required. Arthroplasty, either by excision or replacement of the scaphoid, can only compound the instability and is best avoided. I cannot see that prolonged immobilization in plaster can be justified as a method of treatment of non-union in view of the uncertainty of the outcome and the likelihood that the patient will be unable to work while in plaster.

As you rightly say, problems of nonunion are best avoided by proper management of the original injury.-I am, etc.,

Rowley Bristow Orthopaedic Hospit

T. J. HERBERT

Herbert, T. J., Proceedings of the Royal Society of Medicine. In press. Fisk, G. R., Annals of the Royal College of
Surgeons of England, 1970, 46, 63.

SIR,-While your leading article (5 October, p. 2) reviewed several aspects of the treat ment of this condition, it is surprising that only mention of arthroplasty was made.

I think that any account of non-union of the scaphoid at this time must include prosthetic replacement of the scaphoid bone. ${ }^{2}$ This is often a useful procedure and should be seriously considered among the options open to one in this unfortunate situation, which does occur not infrequently. -I am, etc.

THOMAS G. WADSWORTH

London $\mathbb{W} .1$

Swanson, A. B., Orthopedic Clinics of North America, 1970, 1, 299.

H. M., Proceedings of the Royal Society of Medicine, 1974, 67, 1075 .

\section{Adjustment of Serum Calcium} Measurements: a Correction

SIR,-In our paper on the "Interpretation of Serum Calcium in Patients with $\mathrm{Ab}$ normal Serum Proteins" (15 December, $p$ 643) and in a subsequent letter ( 2 March, p. 393) we made an error in converting our equation from conventional to S.I. units. The equation was calculated using $\mathrm{g} / 100 \mathrm{ml}$ fo albumin instead of $\mathrm{g} / \mathrm{l}$. as recommended by the National Working Party. ${ }^{1}$

The formula-adjusted calcium $=$ calcium -albumin +4.0 (when calcium is in $\mathrm{mg} / 100$ $\mathrm{ml}$ and albumin in $\mathrm{g} / 100 \mathrm{ml}$-converted to S.I. units becomes-adjusted calcium= calcium-0.025 albumin +1.0 (when calcium is in $\mathrm{mmol} / \mathrm{l}$. and albumin in $\mathrm{g} / \mathrm{l}$.). - We are, etc.,

R. B. Payne

A. J. LITTL

R. B. WIILIAMS

Department of Chemical Pathology,

J. R. MINER

St. James's Hospital, Leeds

Baron, D. N., et al., fournal of Clinical Pathology,

\section{Larrey and Débridement}

SIR,-Mr. D. H. Patey (26 October, p. 228) says that is a fortunate error that British surgeons have tended to derive the word "débridement" from "débris." I cannot agree because, in so doing, they have increasingly forgotten its original meaning; and this is one of the rare cases in surgery where a correct etymology may save a limb or a life.

"Débridement" means to unbridle; in this context to relieve tension, actual or potential, by slitting up the fascial envelopes of the muscle compartments. If this is not done widespread muscle necrosis, with its attendant risks of infection and gangrene, may develop after the treatment of a compound fracture, however efficient the initial excision of dead or dying tissue. We owe a great deal to Trueta for reminding us of this at the beginning of the last war.

It has been my misfortune on occasion to have to try to remedy the damage brought about in cases of compound fracture by young surgeons who have never been taught the true meaning of "débridement"; and how can they be blamed when eminent seniors misapply the term to such procedures as the removal of necrotic tissue and sequestra in Pott's disease? Those of us in charge of accident departments should never miss an opportunity of stressing the importance of dividing the deep fascia when dealing with compound injuries. - I am, etc.,

DAVID Le VAY

Withyham,
near Hartfield.

Sussex

${ }_{*}^{*}$ This correspondence is now closed.ED., B.M.f.

\section{P.C.A. Reactions in Monkeys}

SIR,-In their investigations of allergic reactions in an article Dr. D. H. Bryant and his colleagues (8 December 1973, p. 589) used passive cutaneous anaplylaxis (P.C.A.) testing in macaque monkeys as one of a series of methods of delineating human IgG and IgE homocytotropic antibodies. In these studies there were no P.C.A. reactions attributed to IgE at two and four hours after sensitization, but P.C.A. reactions were induced at 24 hours.

We have been studying P.C.A. reactions in monkeys for some time, using human serum from allergic individuals and serum from ascaris-sensitive macaques. Our studies have revealed that there are good and poor recipient macaques for P.C.A. It is not clear at present why this should be so, but we do know that wild-caught macaques are commonly sensitive to ascaris, suggesting an already existing IgE response which might complicate passive transfer reactions. Also, macaques can become sensitive to human serum on repeated transfers. Fortunately, we have a series of home-bred macaques who have no known sensitivity and therefore provide animals in which one would expect a low natural IgE level. In these animals P.C.A. reactions can be carried out using serum from sensitive monkeys or humans. In our tests human reaginic sera from an ascaris-sensitive individual is capable of sensitizing such monkeys for two-, four-, and 24-hour P.C.A. reactions at dilutions of 